\title{
Biochemical properties of xylanases from a thermophilic fungus, Melanocarpus albomyces, and their action on plant cell walls
}

\author{
K ASHOK PRABHU* and RAMESH MAHESHWARI ${ }^{\dagger}$ \\ Department of Biochemistry, Indian Institute of Science, Bangalore 560 012, India \\ *Present address: Department of Biochemistry, Kasturba Medical College, Mangalore 575 001, India \\ ${ }^{\dagger}$ Corresponding author (Fax, 91-80-334-1814; Email, fungi@biochem.iisc.ernet.in).
}

\begin{abstract}
Melanocarpus albomyces, a thermophilic fungus isolated from compost by enrichment culture in a liquid medium containing sugarcane bagasse, produced cellulase-free xylanase in culture medium. The fungus was unusual in that xylanase activity was inducible not only by hemicellulosic material but also by the monomeric pentosan unit of xylan but not by gfucose. Concentration of bagasse-grown culture filtrate protein followed by size-exclusion and anion-exchange chromatography separated four xylanase activities. Under identical conditions of protein purification, xylanase I was absent in the xylose-grown culture filtrate. Two xylanase activities, a minor xylanase IA and a major xylanase IIIA, were purified to apparent homogeneity from bagasse-grown cultures. Both xylanases were specific for $\beta-1,4$ xylose-rich polymer, optimally active, respectively, at $\mathrm{pH} 6 \cdot 6$ and $5 \cdot 6$, and at $65^{\circ} \mathrm{C}$. The xylanases were stable between $\mathrm{pH} 5$ to 10 at $50^{\circ} \mathrm{C}$ for $24 \mathrm{~h}$. Xylanases released xylobiose, xylotriose and higher oligomers from xylans from different sources. Xylanase IA had a $M_{\mathrm{r}}$ of $38 \mathrm{kDa}$ and contained $7 \%$ carbohydrate whereas xylanase IIIA had a $M_{\mathrm{r}}$ of $24 \mathrm{kDa}$ and no detectable carbohydrate. The $K_{\mathrm{m}}$ for larchwood xylan ( $\mathrm{mg} \mathrm{m}^{-1}$ ) and $V_{\max }\left(\mu \mathrm{mol}\right.$ xylose $\mathrm{min}^{-1} \mathrm{mg}^{-1}$ protein) of xylanase IA were 0.33 and 311 , and of xylanase IIIA 1.69 and 500, respectively. Xylanases IA, II and IIIA showed no synergism in the hydrolysis of larchwood glucuronoxylan or oat spelt and sugarcane bagasse arabinoxylans. They had different reactivity on untreated and delignified bagasse. The xylanases were more reactive than cellulase on delignified bagasse. Simultaneous treatment of delignified bagasse by xylanase and cellulase released more sugar than individual enzyme treatments. By contrast, the primary cell walls of a plant, particularly from the region of elongation, were more susceptible to the action of cellulase than xylanase. The effects of xylanase and cellulase on plant cell walls were consistent with the view that hemicellulose surrounds cellulose in plant cell walls.
\end{abstract}

\section{Introduction}

The thermophilic fungi are attracting increasing attention as sources of thermostable xylanases for potential applications in the preparation of paper pulps, for the processing of agro-food raw materials and for enzymatic conversion of hemicellulose in biomass into useful chemicals. Xylanases from the thermophilic fungi Thermoascus aurantiacus (Tan et al 1987; Khandke et al 1989), Thermomyces lanuginosus (= Humicola lanuginosa) (Kitpreechavanich et al 1984; Bennett et al 1998; Anand et al 1990; Gomes et al 1993; Purkathofer et al 1993; Cesar and Mrša 1996), Talaromyces byssochlamydoides
(Yoshioka et al 1981), Humicola grisea var. thermoidea (Monti et al 1991; de Almeida et al 1995), Talaromyces emersoni (Tuohy et al 1993), Chaetomium thermophile var. coprophile (Ganju et al 1989) and Humicola insolens (Düsterhöft et al 1997) have been studied. These studies have shown that xylanases are co-induced in response to xylan or natural substrates containing hemicellulose or even by pure cellulose (Ganju et al 1989). Xylanases are commonly induced with cellulases and secreted into the medium. They are generally single-chain glycoproteins, ranging from 6 to $80 \mathrm{kDa}$, active between $\mathrm{pH} 4.5$ to 6.5 , and at temperatures between $55^{\circ}$ to $65^{\circ} \mathrm{C}$. Geographical isolates of the same thermophilic fungus may differ in

Keywords. Cellulase free-xylanase; Melanocarpus albomyces; thermophilic fungus; hemicellulase; biodegradation; sugarcane bagasse; plant cell wall 
enzyme productivity and in structural and biochemical properties of xylanases (Kitpreechavanich et al 1984; Bennett et al 1998; Cesar and Mrša 1996). Some thermophilic fungi produce multiple forms of xylanases that differ in molecular size, stability, adsorption or activity on insoluble substrates (Tuohy et al 1993; Düsterhöft et al 1997).

We isolated a xylanase-producing thermophilic fungus, Melanocarpus albomyces, from compost by enrichment culture in a liquid medium incorporating sugarcane bagasse as the carbon source (Maheshwari and Kamalam 1985). Besides being a non-sporulating, heterothallic ascomycete, this fungus was noteworthy because it rapidly produced appreciable levels of xylanase activity without contaminating cellulases when grown on sugarcane bagasse - a cheap material available in bulk quantity in the tropics-obviating the use of expensive xylan as the inducer. Moreover, unlike other fungi, xylanase in $M$. albomyces was inducible also by xylose. Furthermore, the fungus grew and produced stable xylanase activity at the alkaline $\mathrm{pH}$ that developed during cultivation in a bagasse-urea medium (Maheshwari and Kamalam 1985). The purpose of this study was to determine if sugarcane bagasse and xylose induce the same spectrum of xylanases, to purify and characterize them and to study biodegradation of plant cell walls by purified xylanase and in combination with cellulase.

\section{Materials and methods}

\subsection{Organism and culture conditions}

The thermophilic fungus Melanocarpus albomyces (Cooney and Emerson) von Arx, strain IIS 68, was isolated from compost (Maheshwari and Kamalam 1985). This strain (ATCC 62358) has been deposited in American Type Culture Collection, Rockville, MD, USA. For the production of xylanase, the fungus was grown for 4 days in $150 \mathrm{ml}$ medium containing $1.5 \%(\mathrm{w} / \mathrm{v})$ sugarcane bagasse in $500 \mathrm{ml}$ flasks at $40^{\circ} \mathrm{C}$ on a gyratory shaker at $240 \mathrm{rpm}$.

\subsection{Xylanase assay}

Xylanase activity was determined using larchwood xylan as substrate as described previously (Maheshwari and Kamalam 1985). The reaction mixture (total volume $2 \mathrm{ml}$ ) containing $0.2 \mathrm{ml}$ of $1 \%(\mathrm{w} / \mathrm{v})$ xylan and a suitably diluted enzyme solution was incubated in buffer. Purified xylanase IA was assayed in $50 \mathrm{mM}, \mathrm{pH} 6.6, \mathrm{Na}-\mathrm{K}$ phosphate buffer. Xylanase IIIA was assayed in $50 \mathrm{mM}, \mathrm{pH} 5 \cdot 6$, sodium acetate buffer. Assays were done at $50^{\circ} \mathrm{C}$ for $30 \mathrm{~min}$. The reaction was stopped by adding $2 \mathrm{ml}$ of alkaline copper solution and the reducing end groups liberated were quantified (Somogyi 1952). One unit of xylanase activity was defined as the amount of enzyme that produced $1 \mu \mathrm{mol}$ of xylose equivalent $\mathrm{min}^{-1}$

\subsection{Enzyme purification}

To the 4-day-old, dark-brown culture filtrate (approximately 4 liter, $\mathrm{pH} 8.8$ ), ammonium sulphate was added to $80 \%$ saturation with continuous stirring. After standing the preparation overnight at $4^{\circ} \mathrm{C}$, the precipitated material was collected by centrifugation and dissolved in $200 \mathrm{ml}$ distilled water. The undissolved material was removed by centrifugation and again ammonium sulphate was added to $\sim 40 \%$ saturation. The precipitate was dissolved in distilled water. The dark brown enzyme solution $(62 \mathrm{ml})$ was desalted in batches by chromatography on a Sephadex G-25 column $(102 \times 2.5 \mathrm{~cm})$ and the enzyme solution was lyophilized. The protein powder was dissolved in $75 \mathrm{mM}$ ammonium acetate buffer ( $\mathrm{pH} 6.2)$ and the enzyme solution $(27 \mathrm{ml})$ applied to a column of DEAESephadex A-50 on which the pigments were absorbed. The xylanase was eluted with the same buffer and enzyme fractions were pooled and lyophilized. The lyophilized protein $(200 \mathrm{mg})$ was dissolved in distilled water and chromatographed in batches $(1 \mathrm{ml})$ on a column of Ultrogel AcA-54 (exclusion limit 90,000 Daltons) and eluted with $100 \mathrm{mM} \mathrm{Na}-\mathrm{K}$ phosphate buffer, pH 6.0 . Appropriate fractions were pooled, lyophilized, desalted and rechromatographed on Ultrogel AcA-54 to obtain a major xylanase. This was further purified by chromatography on a column $(12 \times 1.5 \mathrm{~cm})$ of QAE-Sephadex equilibrated with glycine- $\mathrm{NaOH}$ buffer $(20 \mathrm{mM}, \mathrm{pH} 9 \cdot 0)$. Bound xylanase was eluted with Tris- $\mathrm{HCl}$ buffer $(20 \mathrm{mM}, \mathrm{pH} 7 \cdot 0)$.

\subsection{Analytical methods}

Protein in culture filtrates was precipitated with $10 \%$ $(\mathrm{w} / \mathrm{v})$ TCA before estimation by the method of Lowry et at (1951) using bovine serum albumin as standard. Protein in column chromatography eluate was monitored by absorption at $280 \mathrm{~nm}$. Gel electrophoresis of protein samples was done on $7.5 \%(\mathrm{w} / \mathrm{v})$ polyacrylamide. SDSPAGE of protein samples was done on $12.5 \%$ gel. Total sugar was estimated by the phenol-sulphuric acid (Dubois et al 1956) or the orcinol method (Winzler 1955). Paper chromatography of sugar was done in descending direction using $n$-butanol-ethanol-water $(52: 33: 15 \mathrm{v} / \mathrm{v})$ and detected by the alkaline-silver nitrate method of Trevelyan et al (1950). Per cent hydrolysis (saccharification) of xylans was determined by estimating reducing sugars by the Nelson-Somogyi method (Somogyi 1952) and calculated as: [xylose equivalent produced $(\mathrm{mg}) \times$ $0.94 \times 100] /[x y l a n(\mathrm{mg})]$.

\subsection{Extraction of bagasse hemicellulose}

Sugarcane bagasse was obtained from a sugar factory. It was air-dried, milled and sieved to obtain a powder of particle size approximately $250 \mu \mathrm{m}$. The powder was delipidated by successive extraction with a mixture of 
methanol-benzene $(2: 1, \mathrm{v} / \mathrm{v})$ and acetone in a Soxhlet apparatus for $24 \mathrm{~h}$ to obtain a pale brown-coloured powder. The powder $(10 \mathrm{~g})$ was suspended in distilled water $(500 \mathrm{ml})$, stirred mechanically and heated to $75^{\circ} \mathrm{C}$. Glacial acetic acid $(0.6 \mathrm{ml})$ and sodium chlorite $(7.5 \mathrm{~g})$ were added slowly stirring with two more additions at intervals of $0.5-1.0 \mathrm{~h}$. The material was cooled and filtered and the insoluble residue was washed with distilled water, followed by ethanol and then air-dried to obtain a cream-coloured delignified bagasse $(6.5 \mathrm{~g})$. This was extracted thrice using $150 \mathrm{ml}$ portions of $5 \%$ sodium hydroxide under stirring. The combined extracts were neutralized using glacial acetic acid and the polysaccharides were precipitated by adding ethanol. After standing overnight at $4{ }^{\circ} \mathrm{C}$, the precipitate was collected by centrifugation and dried. The yield of hemicellulose was $2 \cdot 0 \mathrm{~g}$.

\subsection{Preparation of cellulase}

A cellulase used to study biodegradation of cell walls was isolated from culture filtrates of Sporotrichum thermophile as described earlier (Bhat et al 1993). Following DEAE-Sephadex chromatography of culture filtrate protein, a protein fraction that lacked both xylanase and $\beta$-glucosidase activities was further purified by gelfiltration chromatography. It behaved as a single protein band on SDS-PAGE.

\subsection{Preparation of Cuscuta cell wall}

Cell walls of Cuscuta reflexa Roxb. (dodder) were prepared from the regions of cell division $(0-6 \mathrm{~cm}$ from tip), cell elongation $(6-16 \mathrm{~cm})$ and vascular tissue (16-30 cm) (Veluthambi et al 1981). Corresponding segments of the vine were subdivided into smaller pieces and immediately killed in methanol. The tissue was refluxed in a mixture of methanol : chloroform $(3: 1, \mathrm{v} / \mathrm{v})$ to extract lipids, following which it was powdered under liquid nitrogen and extracted with distilled water at $65^{\circ} \mathrm{C}$ until the extract was negative to $\mathrm{I}_{2}-\mathrm{KI}$ solution. The cell wall material was dried in a vacuum dessicator over calcium chloride.

\section{Results}

\subsection{Purification of xylanases}

Multistep procedures involving concentration of culture filtrate protein, gel-filtration and ion-exchange chromatography were required to remove the pigment and separate multiple xylanases from the culture filtrates of $M$. albomyces IIS 68 grown on sugarcane bagasse (table 1). Much of the dark-brown colouring material was strongly adsorbed on DEAE-Sephadex A-50 in Step V.

Table 1. Summary of purification of xylanases from $M$. albomyces grown on sugarcane bagasse.

\begin{tabular}{|c|c|c|c|c|}
\hline Purification step & $\begin{array}{l}\text { Total } \\
\text { volume } \\
(\mathrm{ml})\end{array}$ & $\begin{array}{l}\text { Total activity } \\
\text { (units) }\end{array}$ & $\begin{array}{l}\text { Total protein } \\
\text { (mg) }\end{array}$ & $\begin{array}{l}\text { Specific } \\
\text { activity }\end{array}$ \\
\hline I. Culture filtrate & 4,080 & 45,818 & 1,996 & 23 \\
\hline $\begin{array}{l}\text { II. Ammonium sulphate } \\
\text { precipitation }\end{array}$ & 200 & 44,403 & 1,457 & 31 \\
\hline $\begin{array}{l}\text { III. Ammonium sulphate } \\
\text { reprecipitation }\end{array}$ & 62 & 43,245 & 1,296 & 33 \\
\hline $\begin{array}{l}\text { IV. Sephadex G-25 } \\
\text { chromatography }\end{array}$ & 660 & 38,905 & 1,007 & 38 \\
\hline $\begin{array}{l}\text { V. DEAE-Sephadex A-50 } \\
\text { chromatography }\end{array}$ & 455 & 35,490 & 201 & 177 \\
\hline \multicolumn{5}{|l|}{$\begin{array}{l}\text { VI. Ultrogel AcA-54 } \\
\text { chromatography }\end{array}$} \\
\hline Xylanase 1 & 2 & 766 & 20 & 38 \\
\hline Xylanase II* & 2 & 2,880 & 18 & 160 \\
\hline Xylanase III & 260 & 26,743 & 85 & 314 \\
\hline $\begin{array}{l}\text { VII. Ultrogel AcA-54 } \\
\text { rechromatography of xylanase I } \\
\text { (xylanase IA) }\end{array}$ & 15 & 750 & 17 & 44 \\
\hline $\begin{array}{l}\text { VIII. QAE-Scphadex A-50 } \\
\text { chromatography of xylanase III } \\
\text { (xylanase IIIA) }\end{array}$ & 117 & 12,391 & 62 & 200 \\
\hline
\end{tabular}

*Further purification of this enzyme was not attempted. 
Subsequent gel-filtration chromatography of the xylanaseenriched protein on a column of Ultrogel AcA.54 (Step VI) resolved it into four major peaks, of which three were active on larchwood xylan. The active peaks were designated as xylanase I, II and III, in the order of their elution (figure 1). Xylanase III comprised the major peak, both with respect to protein and enzyme activity. Xylanase I was separated from a minor contaminating protein by rechromatography on Ultrogel AcA-54 (Step VII). The final preparation, xylanase IA, was homogeneous (figure 2). Further purification of xylanase II was not attempted. Xylanase III was chromatographed on QAE-Sephadex A-50 (Step VIII) and was resolved into a major xylanase IIIA that eluted before a minor xylanase IIIB (figure 3). Xylanase IIIA was obtained in a pure form (figure 4) but xylanase IIIB was not purified further.

\subsection{Xylose-induced xylanases}

Compared to the bagasse-culture filtrate, the xyloseculture filtrate was less dark. The total xylanase activity in the bagasse- and xylose-culture filtrates was 10 and 12 units/ml. After DEAE-Sephadex A-50 chromatography, nearly equal amount of total protein was recovered from the two cultures with comparable specific activities (154 and 149, respectively). Equal amounts of the two protein samples were chromatographed separately under identical conditions on an Ultrogel AcA-54 column. In the xylose-grown culture protein eluate, the peak of xylanase activity corresponding to xylanase $I$ in the bagasse-culture protein eluate was absent but xylanase activity peaks II

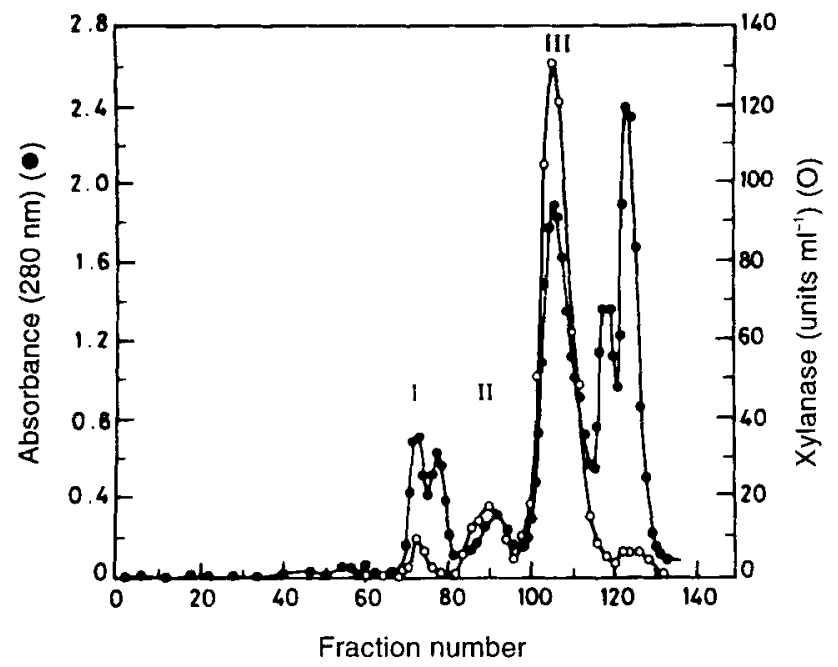

Figure 1. Gel-filtration chromatography of xylanase-enriched protein. Protein obtained after DEAE-Sephadex ion-exchange chromatography was applied on a column of Ultrogel AcA-54 $(160 \times 2 \mathrm{~cm}$, void volume $110 \mathrm{ml})$ and then eluted with phosphate buffer. Three $\mathrm{mi}$ fractions were collected at a flow rate of $15 \mathrm{ml} / \mathrm{h}$ to obtain xylanase I (fractions 70 to 75 ), xylanase II (fractions 84 to 95 ) and xylanase III (fractions 99 to 114). and III were present. The results indicated that bagasse induced an additional form of xylanase than xylose.

\subsection{Biochemical and functional properties of xylanase IA and IIIA}

The molecular mass of xylanases estimated by gelfiltration and SDS-PAGE methods are given in table 2 . The time-course of larchwood xylan hydrolysis by both xylanases was fairly linear up to $60 \mathrm{~min}$. The $\mathrm{pH}$ optimum of xylanase IA was 6.6 at $50^{\circ} \mathrm{C}$ and for xylanase IIIA it was 5.6 , either at $50^{\circ} \mathrm{C}$ or at $65^{\circ} \mathrm{C}$. Both xylanases were stable between pH $5-10$ at $50^{\circ} \mathrm{C}$ (figure 5). Although both xylanases were maximally active at $65^{\circ} \mathrm{C}(20-30 \mathrm{~min}$ assay), they were less stable at this temperature than at $50^{\circ} \mathrm{C}$. Xylanase IA exhibited greater thermostability than xylanase IIIA; it retained $60-80 \%$ of its activity at $50^{\circ} \mathrm{C}$ even after $72 \mathrm{~h}$ incubation (figure 6). Xylanase IIIA was stable at $\mathrm{pH} 9.0$ and retained more than $50 \%$ activity after $24 \mathrm{~h}$ at $50^{\circ} \mathrm{C}$. A puzzling behaviour of xylanase IIIA was that it lost $40-60 \%$ activity in $2 \mathrm{~h}$ at $50^{\circ} \mathrm{C}$, but no further loss occurred up to $24 \mathrm{~h}$.

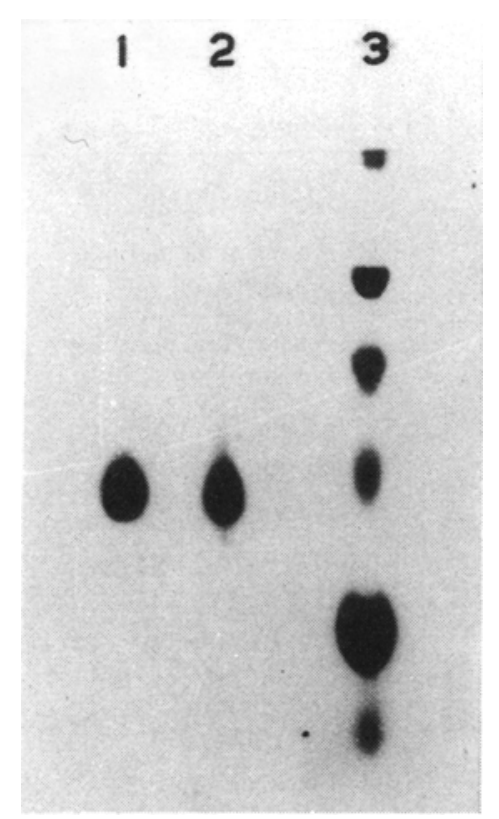

Figure 2. SDS-PAGE of xylanase IA. Lane 1, $40 \mu \mathrm{g}$ enzyme treated with $\beta$-mercaptoethanol. Lane 2 , untreated enzyme $(40 \mu \mathrm{g})$. Lane 3 , protein markers from top: phosphorylase B (97 kDa), bovine serum albumin (66 kDa), ovalbumin (45 kDa), chicken riboflavin carrier protein $(34 \mathrm{kDa})$, soyabean trypsin inhibitor $(20.1 \mathrm{kDa})$ and lysozyme (14.4 kDa) 
Both xylanases hydrolysed larchwood glucuronoxylan, oat spelt and sugarcane bagasse arabinoxylans. They had little activity on native or delignified bagasse, cellulose, starch or lichenan. Paper chromatography of larchwood, oat spelt or sugarcane bagasse hydrolysates showed that xylotriose and xylobiose were produced faster by xylanase IIIA (figure 7) than by xylanase IA (data not shown). The hydrolysates were also analysed by Biogel P-2 chromatography (figure 8 ). In hydrolysates by xylanase IA, a major peak of high molecular weight oligosaccharide eluted at the same position as did standard larchwood xylan. The predominant low molecular weight hydrolysis product from all three xylans was xylobiose $\left(X_{2}\right)$. Appreciable amount of xylotriose $\left(X_{3}\right)$ was produced from oat and bagasse xylans but not from larchwood xylan. None of these xylans yielded xylose as the major product of hydrolysis. Higher oligomers $\left(>X_{3}\right)$ were detected in hydrolysates of oat spelt xylan. In xylanase IIIA hydrolysis products, in addition to the major peak of high molecular weight oligosaccharides, low molecular weight products were xylotriose and xylobiose from all three xylans. As with xylanase IA, xylose was produced in trace amount. Higher oligomers $\left(>X_{3}\right.$ ) were detected in hydrolysates of oat spelt and sugarcane bagasse arabinoxylan but not of larchwood glucuronoxylan.

The reaction velocity increased with increasing concentrations of xylans from larchwood, oat spelt and sugarcane bagasse up to $1000 \mathrm{mg} / \mathrm{l}$ and with higher concentrations of substrate, the reaction reached a plateau, giving a typical hyperbolic substrate/velocity curve. The $K_{\mathrm{m}}$ and $V_{\text {mix }}$ values calculated from Lineweaver-Burk plots are given in table 2 . The carbohydrate content of xylanase IA

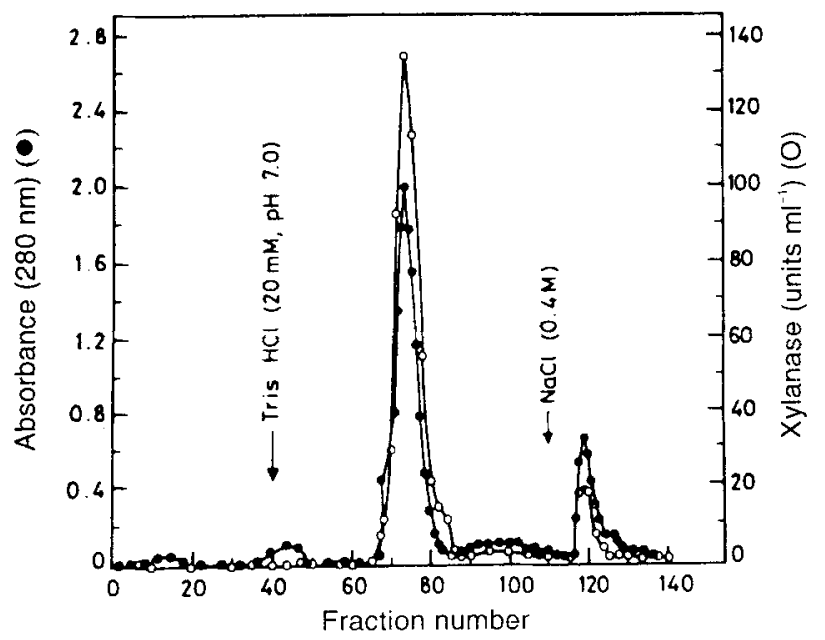

Figure 3. QAE-Sephadex chromatography of xylanase III. Protein was applied on a column pre-equilibrated with glycine$\mathrm{NaOH}$ buffer ( $\mathrm{pH} 9 .(0)$ and then washed with $44 \mathrm{ml}$ buffer. Bound xylanase was eluted using Tris- $\mathrm{HCl}$ buffer $(\mathrm{pH} \mathrm{7.0)}$. Fractions $(1.5 \mathrm{ml})$ were collected to obtain xylanase IIIA (fractions 68 to 81 ) and xylanase IIIB (fractions 116 to 123). and IIIA was determined at protein concentrations of 72 and $144 \mu \mathrm{g}$. Whereas carbohydrate was detected in xylanase IA, it was not detected in xylanase IIIA.

\subsection{Action of xylanases on xylans}

The initial rate of hydrolysis of different xylans by xylanases IA and IIIA was rapid. In $10 \mathrm{~min}, 13-15 \%$ of xylan from larchwood, oat spelt or sugarcane was hydrolysed. Subsequently xylans were hydrolysed slowly up to $48 \mathrm{~h}$. The maximal saccharification of these xylans ( $5 \mathrm{mg})$ in $48 \mathrm{~h}$ by xylanase IA ( 2 unit) was $30 \%, 38 \%$ and $29 \%$, respectively, and by xylanase IIIA $(\sim 2$ unit $)$ it was $26 \%, 27 \%$ and $18 \%$, respectively.

The xylanase preparations, IA, II and IIIA, were used to examine their functional interaction in hydrolysing larchwood xylan. In $20 \mathrm{~min}$ or in $24 \mathrm{~h}$, the saccharification of xylan by a combination of the three xylanases was equal to the arithmetic sum of the saccharification by the individual enzymes, showing the absence of synergy in their action. In $24 \mathrm{~h}$, the combination of three xylanases effected only 2 to $5 \%$ more saccharification than when used individually.

\subsection{Action of xylanases on cell wall material}

A hemicellulose content of $30-35 \%$ in sugarcane bagasse has been reported in literature (Paturau 1982). The

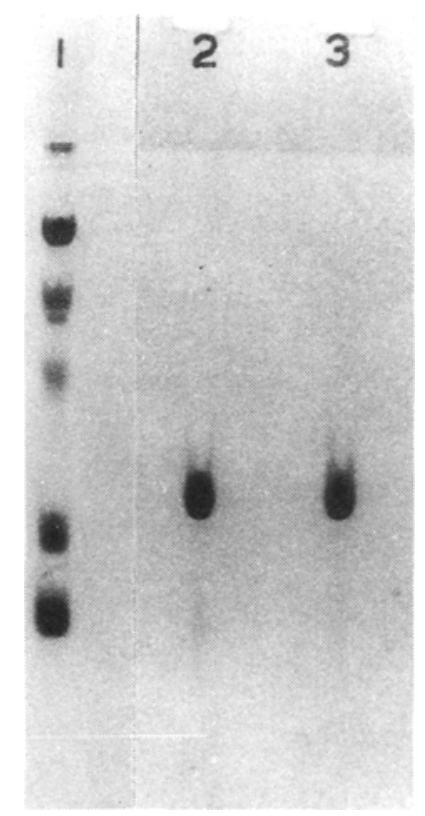

Figure 4. SDS-PAGE of xylanase IIIA. Lane 1. marke: proteins from top: phosphorylase B, bovine serum albumin, chicken riboflavin carrier protein. soyabean trypsin inhibitol and lysozyme. Lane 2 , enzyme $(40 \mu \mathrm{g})$ treated with $\beta$-mercaptoethanol. Lane 3, untreated $(40 \mu \mathrm{g})$ enzyme. 
analysis of sugarcane bagasse used in the present experiments showed that it contained $27 \%$ lignin, $30 \%$ cellulose (alkali-insoluble material), $20 \%$ hemicellulose (alkalisoluble fraction of which xylose comprised nearly $80 \%$ ) and $8 \%$ water-soluble polysaccharides. Xylanases, IA and IIIA, released more sugars from delignified bagasse than from native bagasse (table 3 ) showing the presence of a "lignin barrier" (Wong et al 1988). Untreated bagasse was equally, although poorly, susceptible to the two xylanases, but delignified bagasse was more susceptible to xylanase IIIA than xylanase IA. Biogel P-2 chromatography of $24 \mathrm{~h}$ hydrolysates of delignified bagasse showed that xylanase IA released higher amounts of xylobiose and xylose than xylanase IIIA. In contrast, xylanase IIIA released a greater quantity of higher oligomers than xylanase IA (figure 8). A polysaccharide was apparently solubilized from delignified bagasse upon boiling and was detected in the control lacking the enzyme (figure 8A).

Delignified bagasse was used to compare the individual action of the two xylanases and in combination with a cellulase (table 4 ). The main results were as follows: (i) In the first $24 \mathrm{~h}$, xylanase IIIA released more sugar than xylanase IA but with time xylanase IA released more sugar than xylanase IIIA (compare rows 1 and 2). (ii) $\mathrm{A}$ mixture of xylanase and cellulase released more reducing sugar from delignified bagasse than single enzymes (compare rows 1, 2 and 3 with 4 and 5). (iii) Simultaneous treatment of delignified bagasse by xylanase and cellulase was more effective than successive enzyme treatments (compare total sugar released in rows 4 and 5 with rows 6-9). (iv) Cellulase was more effective on delignified

Table 2. Comparison of xylanase IA and xylanase IIIA of $M$. albomyces.

\begin{tabular}{lll}
\hline Property & Xylanase IA & Xylanase IIIA \\
\hline pH optimum & $6 \cdot 6$ & $5 \cdot 6$ \\
pH stability $\left(28^{\circ} \mathrm{C} \mathrm{or} 50^{\circ} \mathrm{C}\right)$ & $5-10$ & $5-10$ \\
Temperature optimum $\left({ }^{\circ} \mathrm{C}\right)$ & 65 & 65 \\
Thermal stability at $50^{\circ} \mathrm{C}$, & Retains $90 \%$ & Retains $60 \%$ \\
24 h at pH 6.6 or 9.0 & activity & activity \\
Molecular mass (Dalton) & 38,000 & 24,000 \\
Carbohydrate content $(\%)$ & 7 & Not detected \\
Substrate specificity & Xylose-rich & Xylose-rich \\
& polymers & polymers \\
$K_{m}$ for larchwood xylan $(\mathrm{mg} / \mathrm{l})$ & $0 \cdot 30$ & 1.69 \\
$V_{\operatorname{mix}}\left(\mu\right.$ mol xylose min ${ }^{-1} \mathrm{mg}$ & 311 & 500 \\
protein $\left.{ }^{-1}\right)$ & & \\
$V_{\text {max }} / K_{\text {tn }}$ & 1036 & 296 \\
Hydrolysis of xylans $(\%)(48 \mathrm{~h})$ & $29-38$ & $18-27$ \\
Mechanism of action & Endo-acting & Endo-acting \\
Major products of hydrolysis & Xylotriose & Higher \\
& and xylobiose & oligomers, \\
& & xylotriose and \\
& & xylobiose \\
\hline
\end{tabular}

bagasse after it had been pre-treated with xylanase (compare row 3 with rows 6 and 7) than by the reciprocal enzyme treatment (compare sugar released in second $24 \mathrm{~h}$ in rows 7 and 9 with first $24 \mathrm{~h}$ treatment with either xylanase IA or IIIA in rows 1 and 2). (v) Xylanase treatment released more sugar than cellulase (compare rows 1 and 2 with 3 ).

In the above experiment the substrate used was delignified secondary walls of sugarcane. The action of xylanase on the primary cell walls belonging to defined regions of plant was studied. For this the leafless vines of dodder (Cuscuta) was used in which the regions of cell division, cell elongation and vascular tissue differentiation are well defined (Veluthambi et al 1981). In contrast to delignified bagasse, this material was more susceptible to the action of cellulase than of xylanase (table 5). For example, in $48 \mathrm{~h}$ the total sugar $(\mu \mathrm{g})$ released from cells walls by cellulase versus xylanase were as follows: 462 and 80 from the region of vascular tissue; 510 and 60 from the region of cell elongation, and 407 and 38 from the region of cell division. Xylanase and cellulase when used together had a nearly additive effect in releasing sugars from all regions of the vine. Regard-

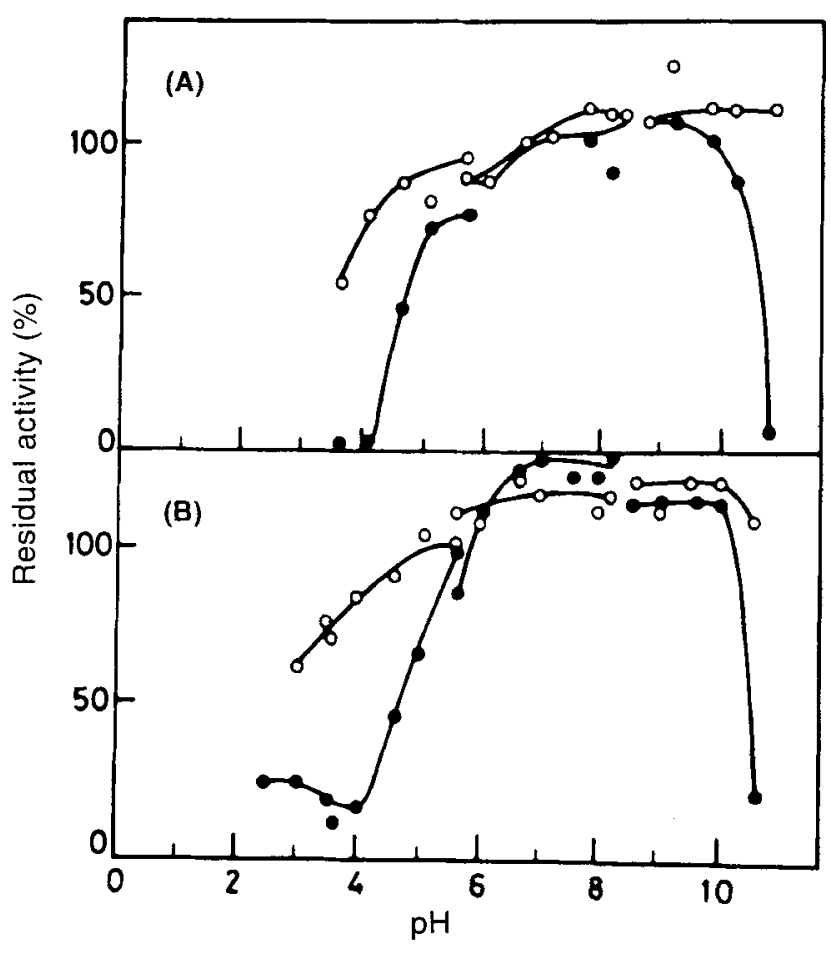

Figure 5. Effect of pH on stability of xylanase IA and IIIA. (A) Xylanase IA. (B) Xylanase IIIA. The enzymes were incubated at $28^{\circ} \mathrm{C}(\mathrm{O})$ and $50^{\circ} \mathrm{C}(\bullet)$ for $24 \mathrm{~h}$. The buffer systems $(50 \mathrm{mM})$ were glycine- $\mathrm{NaOH}$ ( $\mathrm{pH} 2.5$ to 3.5 ), sodium acetate ( $\mathrm{pH} 3.6$ to 5.6 ) sodium-potassium phosphate (pH 5.6 to 8.2 ) and glycine- $\mathrm{NaOH}(\mathrm{pH} 8.6$ to 10.6 ). The activity of diluted samples of enzymes before incubation in different buffers was taken as $100 \%$. 
less of the region of the vine, the total sugars released in $48 \mathrm{~h}$ by xylanase treatment followed by successive treatments of xylanase and cellulase was more than in the reciprocal treatment (rows 4 and 5). Finally the data showed that cell walls from the region of cell elongation was more susceptible to the action of cellulase or the simultaneous actions of xylanase and cellulase.

\section{Discussion}

M. albomyces is not a cellulolytic fungus (Maheshwari and Kamalam 1985) and the purified xylanases showed very little capacity to degrade native bagasse. Yet, satisfactory mycelial growth of the fungus was always visible in a medium incorporating sugarcane bagasse as the carbon source. Presumably, after autoclaving in the medium the bagasse was structurally modified and facilitated the access of xylanases to the hemicellulosic component (table 3 ).

The gel-filtration profile of the culture filtrate protein showed that $M$. albomyces produces multiple xylanase activities in media incorporating sugarcane bagasse or xylose. Four xylanases were isolated from bagasse-grown culture filtrates: xylanase I, II, IIIA and IIIB. The similar gel-filtration chromatography profile, electrophoretic mobility and xylan hydrolysis products of one major xylanase from bagasse- and xylose-grown cultures suggested that xylanase III $\left(M_{\mathrm{r}} 24 \mathrm{kDa}\right)$ may be a common enzyme that is induced by hemicellulosic material or xylose. Xylanase IA $\left(M_{\mathrm{r}} 38 \mathrm{kDa}\right)$ was not present in xylose-grown culture showing that in $M$. albomyces the

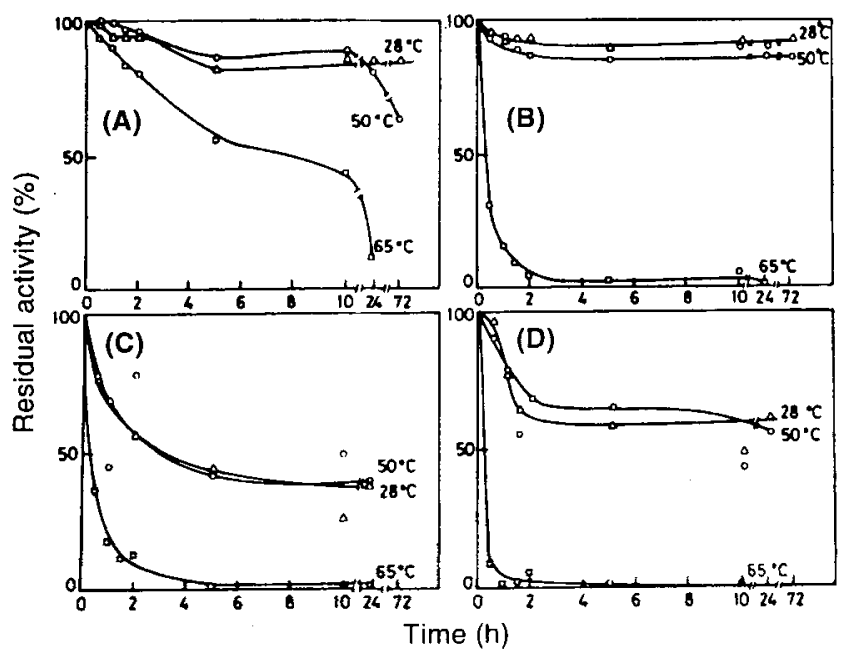

Figure 6. Thermal stability of xylanases. Xylanases in buffer (pH $6.6 \mathrm{Na}-\mathrm{K}$ phosphate, $\mathrm{pH} 5.6 \mathrm{Na}$-acetate and $\mathrm{pH} 9.0$ glycine- $\mathrm{NaOH}$, all $50 \mathrm{mM}$ ) were incubated at the indicated temperatures for up to $72 \mathrm{~h}$ and aliquots assayed at intervals. (A) Xylanase IA, pH 6.6. (B) Xylanase IA, pH 9.0. (C) Xylanase IIIA, pH 5.6. (D) Xylanase IIIA, pH 9.0. nature of the inducing substrate can determine the forms of xylanase produced. An analogous situation was reported with respect to the endoglucanases in Trichoderma reesei QM 9414 (Messner et al 1988). Here sophorose, lactose and cellulose induced, respectively, two, four and five forms of the enzyme. The number of xylanases in $M$. albomyces grown with xylose or bagasse was reproducible.

Compared to xylanase IIIA, xylanase IA was more thermostable. Both xylanases of $M$. albomyces are more thermostable than of the mesophilic fungus $T$. reese $i$ which was completely inactivated at $65^{\circ} \mathrm{C}$ in $1 \mathrm{~h}$ (Dekker 1983). The appearance of a mixture of reaction products of lower degree of polymerization than xylan showed that both xylanases of $M$. albomyces are endo-acting enzymes. The peak areas of the oligomeric products in the xylan hydrolysates (figure 8) suggest that the two xylanases differ in their randomness of attack on xylan. As has

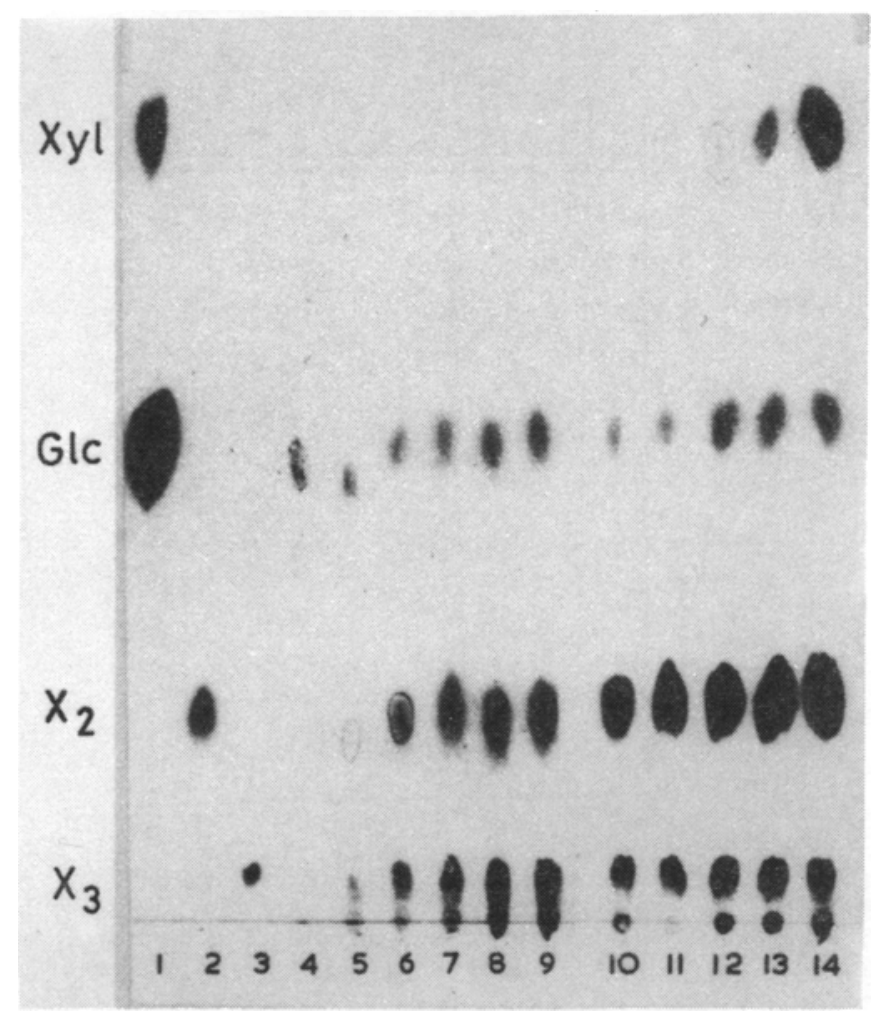

Figure 7. Products of Iarchwood xylan hydrolysis by xylanasc IIIA. Xylan $(25 \mathrm{mg})$ was incubated with xylanase IIIA $(\sim 2.0$ unit) in $2.5 \mathrm{ml}$ of $\mathrm{Na}-\mathrm{K}$ phosphate buffer $(50 \mathrm{mM}, \mathrm{pH} 6.0)$ at $50^{\circ} \mathrm{C}$ with intermittent shaking in covered tubes. Aliquots were heated in a boiling water bath and analysed by paper chromatography. Lane 1, standard glucose (Glc) and xylose (Xyl). Lane 2 , standard xylobiose $\left(X_{2}\right)$. Lane 3 , standard xylotriose $\left(X_{3}\right)$. Lane 4, control (no enzyme). Lanes 5 to 9, hydrolysis for $5,10,15,20$ and $30 \mathrm{~min}$, respectively. Lanes 10 to 14 , hydrolysis for $1,2,4,8$ and $24 \mathrm{~h}$, respectively. 
frequently been observed in reaction of cellulose with cellulase enzymes, the rate of xylan hydrolysis by purified xylanases slowed down after the initial rapid hydrolysis for $10 \mathrm{~min}$. This may be explained on the assumption that the most accessible glycosidic bonds are hydrolysed rapidly leaving a residue, which is increasingly resistant. The accumulation of resistant xylan residues has been reported (Dekker and Richards 1975).

The xylanase productivity of $M$. albomyces strain IIS 68 is lower than of $T$. lanuginosus (Bennett et al 1998; Cesar and Mrša 1996), T. aurantiacus (Yu et al 1987) or Paecilomyces varioti (Krishnamurthy 1989). In T. aurantiacus (Tan et al 1987; Khandke et al 1989) and P. varioti (Krishnamurthy 1989), the xylanase activity was so high

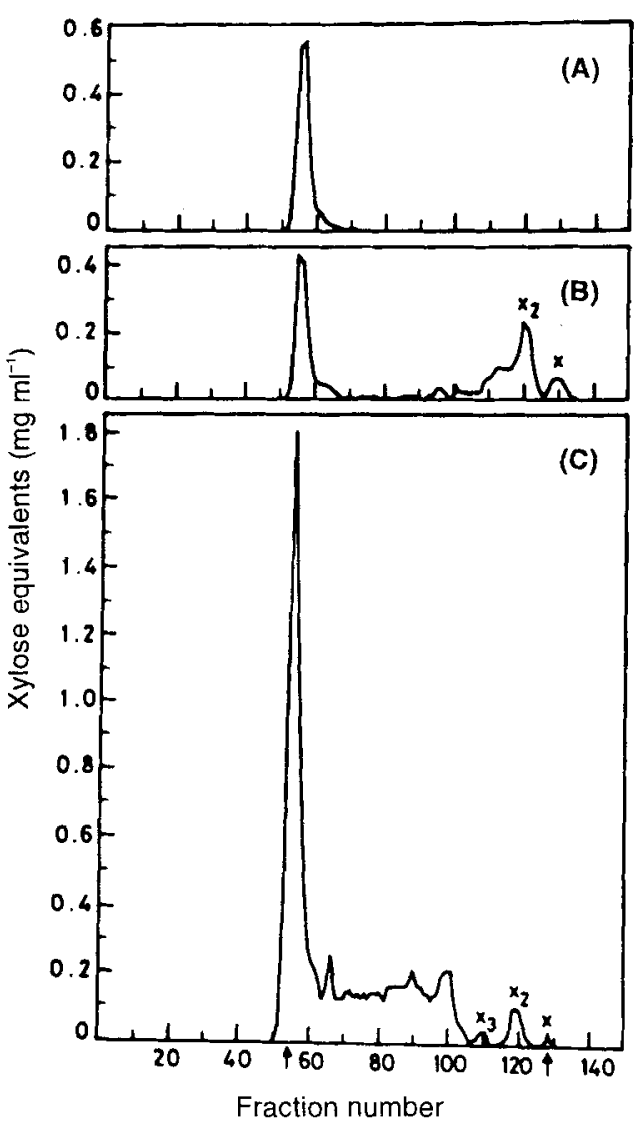

Figure 8. Analysis of hydrolysis products of delignified bagasse. Substrate $(100 \mathrm{mg})$ was incubated in $5 \mathrm{ml}$ phosphate buffer (50 mM, pH 6.0) without enzyme (A) or with $50 \mu \mathrm{g}$ xylanase IA (B) or $50 \mu \mathrm{g}$ xylanase IIIA (C). The reaction was terminated by heating in boiling water bath for $5 \mathrm{~min}$. The hydrolysates were clarified by centrifugation, applied on a Biogel P-2 column $(153 \times 1.5 \mathrm{~cm})$ and eluted with distilled water. Fractions $(1 \mathrm{ml})$ were monitored for total sugar by the orcinol method. The column was calibrated by detcrmining the elution volumes of larchwood xylan and xylose. Xylotriose $\left(\mathrm{X}_{3}\right)$ and xylobiose $\left(\mathrm{X}_{2}\right)$ were identified based on the ratio of total sugar to the reducing sugar value and finally by paper chromatography using authentic standards. Left arrow, elution volume of larchwood xylan; right arrow, elution volume of xylose. that only 3- to 4-fold purification of culture filtrates yielded homogeneous protein and gram amounts of crystalline xylanases. Because of the low solubility and the compositional variability of xylan (substrate), the differences in the mode of action of xylanases and in the nature of products formed as also the differences in properties of xylanases produced by different strains of the same fungus (Kitpreechavanich et al 1984; Anand et al 1990), only an approximate comparison of catalytic efficiency of xylanases can be made. The $V_{\max } / K_{\mathrm{m}}$ value for $M$. albomyces xylanase IA on larchwood is 1036 and for xylanase IIIA it is 296. For xylanases of other thermophilic fungi these values are 36 for $T$. aurantiacus (Tan et al 1987), 915 for T. lanuginosus (Anand et al

Table 3. Action of $M$. albomyces xylanases on sugarcane bagasse ${ }^{u}$.

\begin{tabular}{lccc}
\hline & \multicolumn{3}{c}{ Sugar released $(\mu \mathrm{g})$} \\
\cline { 2 - 4 } Enzyme & Untreated & Autoclaved & Delignified \\
\hline Xylanase IA & 71 & 161 & 661 \\
Xylanase IIIA & 57 & 127 & 1250 \\
\hline
\end{tabular}

"Bagasse $(10 \mathrm{mg})$ was incubated in $1 \mathrm{ml} \mathrm{Na}-\mathrm{K}$ phosphate buffer $(50 \mathrm{mM}, \mathrm{pH} 6.0$ ) with 0.4 unit xylanase IA or 0.3 unit xylanase IIIA for $24 \mathrm{~h}$ at $50^{\circ} \mathrm{C}$. Sugar released was estimated by the phenol-sulphuric acid method (Dubois et al 1956).

Table 4. Individual, simultaneous and sequential action of xylanase and cellulase on delignified bagasse".

\begin{tabular}{lrcc}
\hline & \multicolumn{3}{c}{ Total sugar released $(\mu \mathrm{g})$} \\
\cline { 2 - 4 } Enzyme & $0-24 \mathrm{~h}$ & $24-48 \mathrm{~h}$ & Total $(48 \mathrm{~h})$ \\
\hline 1. Xylanase IA & 660 & 425 & 1085 \\
2. Xylanase IIIA & 1250 & 264 & 1514 \\
$\begin{array}{l}\text { 3. Cellulase } \\
\text { 4. Xylanase IA + cellulase }\end{array}$ & 982 & 150 & 257 \\
$\begin{array}{l}\text { 5. Xylanase IIIA + cellulase } \\
\text { 6. Xylanase IA followed by } \\
\text { cellulase }\end{array}$ & 1593 & 696 & 1786 \\
$\begin{array}{l}\text { 7. Cellulase followed by } \\
\quad \text { xylanase IA }\end{array}$ & 136 & 675 & 2264 \\
$\begin{array}{l}\text { 8. Xylanase IIlA followed } \\
\text { by cellulase }\end{array}$ & 1243 & 407 & 1071 \\
$\begin{array}{l}\text { 9. Cellulase followed by } \\
\quad \text { xylanase IIIA }\end{array}$ & 187 & 1043 & 1230 \\
\hline
\end{tabular}

"Hydrolysis of substrate $(10 \mathrm{mg})$ was carried out in $1 \mathrm{ml}$ of phosphate buffer $(50 \mathrm{mM}, \mathrm{pH} 6.0)$ for $24 \mathrm{~h}$ at $50^{\circ} \mathrm{C}$. The concentration (per $\mathrm{ml}$ ) of enzymes were as follows: 0.4 unit xylanase IA, 0.3 unit xylanase IIIA and 0.2 unit cellulase. Test tubes were covered with Parafilm and incubated with intermittent shaking. After $24 \mathrm{~h}$, the reaction was terminated by boiling ( $5 \mathrm{~min}$ ) and supernatant was used for total sugar estimation by phenol-sulphuric acid method. The residue was treated with either a fresh batch of same enzyme or the desired enzyme as indicated and total sugar was again estimated after $24 \mathrm{~h}$. 
Table 5. Action of cellulase and xylanase on Cuscuta cell wall ${ }^{a}$.

\begin{tabular}{|c|c|c|c|c|c|c|}
\hline \multirow[b]{3}{*}{ Treatment } & \multicolumn{6}{|c|}{ Sugar $(\mu \mathrm{g})$ released from cell walls from the region of: } \\
\hline & \multicolumn{2}{|c|}{ Vascular tissue } & \multicolumn{2}{|c|}{ Cell elongation } & \multicolumn{2}{|c|}{ Cell division } \\
\hline & $0-24 \mathrm{~h}$ & $24-48 \mathrm{~h}$ & $0-24 \mathrm{~h}$ & $24-48 \mathrm{~h}$ & $0-24 \mathrm{~h}$ & $24-48 \mathrm{~h}$ \\
\hline 1. Xylanase & 52 & 28 & 38 & 22 & 26 & 12 \\
\hline 2. Cellulase & 189 & 273 & 200 & 310 & 170 & 237 \\
\hline 3. Xylanase + cellulase & 235 & 308 & 241 & 395 & 250 & 235 \\
\hline $\begin{array}{l}\text { 4. Xylanase followed by } \\
\text { cellulase }\end{array}$ & 60 & 268 & 39 & 315 & 42 & 225 \\
\hline $\begin{array}{l}\text { 5. Cellulase followed by } \\
\text { xylanase }\end{array}$ & 180 & 76 & 202 & 79 & 161 & 52 \\
\hline
\end{tabular}

"Cell wall material $(10 \mathrm{mg})$ was incubated with xylanase IIIA $(0.3 \mathrm{unit})$ and/or cellulase $\left(0.2\right.$ unit) in $1 \mathrm{ml}$ of phosphate buffer $\left(50 \mathrm{mM}, \mathrm{pH} 6.0,50^{\circ} \mathrm{C}\right)$ in covered tubes with intermittent shaking. After $24 \mathrm{~h}$, the reaction was terminated by boiling $(5 \mathrm{~min})$ and total sugar estimated in the supernatant. The residue was treated with either the same enzyme or the indicated enzyme and the total sugar was estimated again after $24 \mathrm{~h}$ incubation.

1990), 480 for P. varioti (Krishnamurthy 1989) and 26 and 69 for forms 1 and 2, respectively of Humicola grisea (Monti et al 1991). Inasmuch as M. albomyces produces appreciable levels of xylanase on sugarcane bagasse without contaminating cellulase or $\beta$-xylosidase, and as the xylanases have desirable $\mathrm{pH}$ and temperature stability and kinetic characteristics, the screening of $M$. albomyces strains and optimization of the culture parameters should be a future objective.

Xylanase IA and IIIA of $M$. albomyces did not show synergism when used in combination. This observation is different from that in Aspergillus niger (Takenishi and Tsujisaka 1975), T. byssochlamydoides (Yoshioka et al 1981) and Trichoderma harzianum (Wong et al 1986) where combination of xylanases increased the overall hydrolysis of xylan by 13-30\%. Co-operative action was also not observed between xylanases from Thielavia terrestris and Thermoascus crustaceus (Gilbert et al 1993). The lack of synergism between xylanases may be because the enzyme forms prefer the same xylosidic bonds, or the products of one xylanase are not a substrate for the other xylanase or because of a combination of these reasons. An interesting observation was that on xylan, xylanase IA showed a higher reactivity than xylanase IIIA but on delignified bagasse the result was the opposite (table 3 ). Presumably the smaller sized xylanase IIIA could permeate faster into bagasse than xylanase IA. The pore size of a cell wall can be an important factor in its enzymatic degradation. It has been suggested that the functional significance of multiple xylanases differing in molecular size may lie in their access into cell walls of variable architecture, permitting efficient degradation of lignocellulosic substrates (Wong et al 1988). Multiple xylanases were also reported in Magnaporthe grisea grown on cell walls as the carbon source (Wu et al 1995).
The treatment of bagasse (table 4) and Cuscuta cell walls (table 5) by cellulase released 1.3- to 3 -fold more sugar if the materials were pre-treated with xylanase. The observation is consistent with the view that in plant cell wall, cellulose microfibrils are covered by hemicellulose (McNeil et al 1984). The Cuscuta cell walls were more susceptible to the action of cellulase than xylanase (table 5), suggesting that cellulose was the chief constituent of the primary cell walls. The cell walls from the cell elongation region were comparatively more susceptible to cellulase than from other region of the plants. In this region of the plant the cellulose fibers may be relatively free, i.e., they are capable of sliding with respect to each other. In other words, one of the important factors in cell elongation in the plant cell may be that hemicellulose has not covered the cellulose microfibrils to impede their movement. In the present experiments only a single cellulase and a xylanase was used to study their contributions in the biodegradation of cell walls. The use of different polysaccharidases of different molecular sizes and specificities would facilitate the analyses of the complex structural configurations of polysaccharides in the cell wall and help in evolving biodegradative procedures for plant biomass. As the active component of the microflora of the decomposing masses of vegetable matter, the thermophilic fungi are expected to be an excellent source of a diversity of polysaccharidedegrading enzymes.

\section{Acknowledgement}

This work was supported by the Department of Science and Technology, New Delhi. 


\section{References}

Anand L, Krishnamurthy S and Vithayathil P J 1990 Purification and properties of xylanase from the thermophilic fungus, Humicola lanuginosa (Griffon and Maublanc) Bunce; Arch. Biochem. Biophys. 276 546-553

Bennett N A, Ryan J, Biely P, Vrsanska L, Kremnicky L, Macris B J, Kekos D, Christakopoulos P, Katapodis P, Claeyssens M. Nerinckx W. Ntauma P and Bhat M K 1998 Biochemical and catalytic properties of an endoxylanase purified from the culture filtrate of Thermomyces lanuginosus ATCC 46882; Carbohydr. Res. 306 445-455

Bhat K M, Gaikwad J S and Maheshwari R 1993 Purification and characterization of an extracellular $\beta$-glucosidase from the thermophilic fungus Sporotrichum thermophile and its influence on cellulase activity; J. Gen. Microbiol. 139 2825-2832

Cesar T and Mrša V 1996 Purification and properties of the xylanase produced by Thermomyces lanuginosus; Enzyme Microb. Technol. 19 289-296

de Almeida E M, de Lourdes M, Polizeli T M, Terenzi H F and Jorge J A 1995 Purification and biochemical characterization of $\beta$-xylosidase from Humicola grisea var. thermoidea; FEMS Microbiol. Lett. 130 171-176

Dekker R F H 1983 Bioconversion of hemicellulose: Aspects of hemicellulase production by Trichoderma reesei QM9414 and enzymic saccharification of hemicellulose; Biotechnol. Bioeng. 25 1127-1146

Dekker R F H and Richards G N 1975 Purification, properties, and mode of action of hemicellulase II produced by Ceratocystis paradoxa; Carbohydr. Res. 42 107-123

Dubois M, Gilles K A, Hamilton J K, Rebers P A and Smith F 1956 Colorimetric method for determination of sugars and related substances; Anal. Chem. 28 350-356

Düsterhöft E-M, Linssen V A J M, Voragen A G J and Beldman G 1997 Purification, characterization, and properties of two xylanases from Humicola insolens; Enzyme Microb. Technol. $20437-445$

Ganju R K, Vithayathil P J and Murthy S K 1989 Purification and characterization of two xylanase from Chatomium thermophile var. coprophile; Can. J. Microbiol. 35 836-842

Gilbert M, Yaguchi M, Watson D C, Wong K K Y, Breuil C and Saddler J N 1993 A comparison of two xylanases from the thermophilic fungi Thielavia terrestris and Thermoascus crustaceus; Appl. Microbiol. Technol. 40 508-514

Gomes J, Gomes I, Kreiner W, Esterbauer H, Sinner M and Steiner W 1993 Production of high level of cellulase-free and thermostable xylanase by a wild strain of Thermomyces lanuginosus using beechwood xylan; J. Biotechnol. 30 283-297

Khandke K M, Vithayathil P J and Murthy S K 1989 Purification of xylanase, $\beta$-glucosidase, endocellulase and exocellulase from a thermophilic fungus Thermoascus aurantiacus; Arch. Biochem. Biophys. 274 491-500

Kitpreechavanich V, Hayashi $M$ and Nagai S 1984 Purification and properties of endo-1,4- $\beta$-xylanase from Humicola lanuginosa; J. Ferment. Technol. 5 415-420

Krishnamurthy S 1989 Purification and properties of xylanase and $\beta$-glucosidase elaborated by the thermophilic fungus Paecilomyces varioti Bainier, Ph.D. Thesis, Indian Institute of Science, Bangalore

Lowry O H, Rosebrough N J, Farr A L and Rondall R J 1951 Protein measurement with the Folin phenol reagent; J. Biol. Chem. 193 265-275
Maheshwari R and Kamalam P T 1985 Isolation and culture of a thermophilic fungus, Melanocarpus albomyces, and factors influencing the production and activity of xylanase; J. Gen. Microbiol. 131 3017-3027

McNeil M, Darvill A G, Fry S C and Albersheim P 1984 Structure and function of the primary cell walls of plants; Annu. Rev. Biochem. 53 625-663

Messner R, Gruber G and Kubicek C P 1988 Differential regulation of synthesis of multiple forms of specific endoglucanases by Trichoderma reesei QM 9414; J. Bacteriol. 32 277-352

Monti R, Terenzi H F and Jorge J A 1991 Purification and properties of an extracellular xylanase from the thermophilic fungus Humicola grisea var. thermoidea; Can. J. Microbiol. $37675-681$

Paturau J M 1982 By-products of the cane sugar industry: An introduction to their industrial utilization (Amsterdam: Elsevier)

Purkarthofer H, Sinner M and Steiner W 1993 Cellulase-free xylanase from Thermonyces lanuginosus: Optimization of production in submerged and solid-state culture; Enzyme Microb. Technol. 15 677-682

Somogyi M 1952 Notes on sugar determination; J. Biol. Chem. $19519-23$

Takenishi S and Tsujisaka Y 1975 On the modes of action of three xylanases produced by a strain of Aspergillus niger van Tieghem; Agric. Biol. Chem. 39 2315-2323

Tan L U L, Mayers P and Saddler J N 1987 Purification and characterization of a thermostable xylanase from a thermophilic fungus Thermoascus aurantiacus; Can. J. Microbiol. 33 689-692

Trevelyan W E, Procter D P and Harrison J S 1950 Detection of sugars on paper chromatograms; Nature (London) $166444-445$

Tuoby M G, Puls J, Claeyssens M, Vrsanska M and Coughlan M P 1993 The xylan-degrading enzyme system of Talaromyces emersonii: novel enzymes with activity against aryl $\beta$-D-xylosides and unsubstituted xylans; Biochem. J. 290 $515-523$

Veluthambi K, Mahadevan $S$ and Maheshwari $R \quad 1981$ Trehalose toxicity in Cuscuta reflexa. Correlation with low trehalase activity; Plant Physiol. 68 1369-1374

Winzler R J 1955 Determination of serum glycoproteins; Methodls Biochem. Analysis 2 279-304

Wong K K Y, Tan L U L and Saddler J N 1988 Multiplicity of $\beta$-1,4-xylanase in microorganisms: Functions and applications; Microbiol. Rev. 52 305-317

Wong K K Y, Tan L U L, Saddler J N and Yaguchi M 1986 Purification of a third distinct xylanase from the xylanolytic system of Trichoderma harzianum; Can. J. Microbiol. 32 $570-576$

Wu S C, Kaufmann S, Darvill A G and Albersheim P 1995 Purification, cloning and characterization of two xylanases from Magnaporthe grisea, the rice blast fungus; Mol. Plant Microbe Interact. 8 506-514

Yoshioka $\mathrm{H}$, Nagato $\mathrm{N}$, Chavanich $\mathrm{S}$, Nilubol $\mathrm{N}$ and Hayashida S 1981 Purification and properties of thermostable xylanase from Talaromyces byssochlamydoides YH-50; Agric. Biol. Chem. 45 2425-2432

Yu E K C, Tan L U L, Chan M K-H. Deschatelets L and Saddler J N 1987 Production of thermostable xylanase by a thermophilic fungus, Thermoascus aurantiacus; Enzyme Microb. Technol. 9 16-24 